Vol. 7, Nomor 2, Oktober 2013

\title{
Tantangan Pengembangan Pendidikan Keguruan di Era Global
}

\author{
Fitri Oviyanti \\ IAIN Raden Fatah Palembang \\ Email: fitrioviy@yahoo.com
}

\begin{abstract}
Globalization barrage pass major changes to the world order as a whole. This era is characterized by the process of life worldwide, the advancement of science and technology, especially in the field of communication as well as the transformation and cross-cultural. Changes brought about by globalization are also experienced by the world of education with teachers as practitioners. Challenges faced by teachers in the global era, such as the development of science and technology are so rapid and fundamental; moral crisis that swept the nation and the state, social crisis and a crisis of identity as a nation. All that obviously requires prospective teachers and qualified professionals. Teacher education programs must be able to provide excellent service to the students so that they can establish qualified teacher. Improving the quality of education will foster public confidence that still exist in the future?
\end{abstract}

Keywords: Teacher's education and Globalization.

\begin{abstract}
Abstrak
Globalisasi mewariskan rentetan perubahan besar pada tatanan dunia secara menyeluruh. Era ini ditandai dengan proses kehidupan mendunia, kemajuan ilmu pengetahuan dan teknologi, terutama dalam bidang transformasi dan komunikasi serta terjadinya lintas budaya. Perubahan yang dibawa oleh globalisasi ini juga dialami oleh dunia pendidikan dengan guru sebagai praktisinya. Tantangan yang dihadapi guru di era global, seperti perkembangan ilmu pengetahuan dan teknologi yang begitu cepat dan mendasar; krisis moral yang melanda bangsa dan negara, krisis sosial dan krisis identitas sebagai bangsa. Semua itu jelas menuntut calon guru yang profesional dan bermutu. Program pendidikan guru harus mampu memberikan pelayanan prima kepada mahasiswa sehingga mampu mencetak guru yang berkualitas. Peningkatan mutu pendidikan ini akan menumbuhkan kepercayaan masyarakat sehingga tetap eksis di masa datang.
\end{abstract}

Kata kunci: pendidikan keguruan dan globalisasi 


\section{A. Pendahuluan}

Pendidikan adalah investasi sumber daya manusia (SDM) jangka panjang yang mempunyai nilai strategis bagi kelangsungan peradaban manusia di dunia. Salah satu komponen penting dalam pendidikan adalah guru. Guru dalam konteks pendidikan mempunyai peranan yang besar dan strategis. Hal ini disebabkan karena guru yang berada di barisan terdepan dalam pelaksanaan pendidikan. Guru yang langsung berhadapan dengan peserta didik untuk mentransfer ilmu pengetahuan dan teknologi, sekaligus mendidik dengan nilai-nilai positif melalui bimbingan dan keteladanan. Guru adalah praktisi pendidikan yang sesungguhnya.

Mengingat strategisnya peran guru dalam pendidikan, apalagi di era global ini, maka kebutuhan akan guru yang berkualitas menjadi sebuah keniscayaan demi masa depan bangsa yang gemilang. Kebutuhan akan guru yang berkualitas yang semakin tinggi saat ini harus disikapi secara positif oleh para pengelola pendidikan guru. Respons positif ini harus ditunjukkan dengan senantiasa meningkatkan mutu program pendidikan yang ditawarkannya. Perbaikan mutu pendidikan pada jenjang pendidikan tinggi ini jelas akan membawa dampak positif bagi penciptaan guru yang berkualitas kelak di kemudian hari.

\section{B. Pendidikan Keguruan}

Dalam Pengertian yang sederhana, guru adalah orang yang memberikan ilmu pengetahuan kepada anak didik. Guru dalam pandangan masyarakat adalah orang yang melaksanakan pendidikan di tempat-tempat tertentu, baik lembaga pendidikan formal maupun nonformal. Guru, menurut Zakiah Dradjat adalah pendidik profesional, karenanya secara implisit ia telah merelakan dirinya menerima dan memikul sebagian tanggung jawab pendidikan yang terpikul di pundak orang tua. Guru adalah suatu sebutan jabatan, posisi, dan profesi bagi seseorang yang mengabdikan dirinya dalam bidang pendidikan melalui interaksi edukatif secara terpola, formal, dan sistematis.

Dalam UU Nomor 14 Tahun 2005 tentang Guru dan Dosen, dinyatakan bahwa Guru adalah pendidikan profesional dengan tugas utama mendidik, mengajar, membimbing, mengarahkan, melatih, menilai, dan mengevaluasi peserta didik pada jalur pendidikan formal, pada jenjang pendidikan dasar dan pendidikan menengah. 
Persatuan Guru Republik Indonesia (PGRI) telah merealisasikan Pengertian profesi keguruan untuk pendidikan di Indonesia sebagai berikut:

1. Profesi keguruan adalah suatu bidang pengabdian/dedikasi kepada kepentingan anak didik dalam perkembangannya menuju kesempurnaan manusiawi.

2. Para anggota profesi keguruan, terikat oleh pola sikap dan perilaku guru yang dirumuskan dalam kode etik guru Indonesia.

3. Para anggota profesi keguruan, dituntut untuk menyelesaikan suatu proses pendidikan persiapan jabatan yang relatif panjang.

4. Para anggota profesi keguruan terpanggil untuk senantiasa menyegarkan serta menambah pengetahuan.

5. Para anggota harus memiliki kecakapan/keterampilan teknis yang mampu menyentuh nilai-nilai kemanusiaan yang mendasar.

6. Para anggota profesi keguruan perlu memiliki sikap bahwa jaminan tentang hak-hak profesional harus seimbang dan merupakan imbalan dari profesi profesionalnya.

National Education Association (NEA) mengutarakan ciri-ciri profesi keguruan sebagai berikut:

1. Jabatan yang melibatkan kegiatan intelektual.

2. Jabatan yang menggeluti suatu batang tubuh ilmu yang khusus.

3. Jabatan yang memerlukan persiapan profesional yang lama. Bandingkan dengan pekerjaan yang memerlukan latihan umum belaka.

4. Jabatan yang memerlukan latihan dalam jabatan yang berkesinambungan.

5. Jabatan yang menjanjikan karier hidup dan keanggotaan yang permanen.

6. Jabatan yang menentukan (standar) sendiri.

7. Jabatan yang lebih mementingkan layanan di atas keuntungan pribadi.

8. Jabatan yang mempunyai organisasi profesional yang kuat dan terjalin erat.

\section{Era Global: Pengertian dan Karakteristik}

Era global adalah sebuah perubahan sosial, berupa bertambahnya keterkaitan di antara masyarakat dan elemen-elemen yang 
terjadi akibat transkulturasi perkembangan teknologi di bidang transportasi dan komunikasi yang memfasilitasi pertukaran budaya dan ekonomi internasional. Globalisasi juga dimaknai dengan gerakan mendunia, yaitu suatu perkembangan pembentukan sistem dan nilai-nilai kehidupan yang bersifat global. Setidaknya terdapat tiga Karakteristik masyarakat di abad 21, yaitu:

1. Masyarakat Teknologi

Masyarakat teknologi yang dimaksud adalah suatu masyarakat yang telah melek teknologi dan menggunakan berbagai aplikasi teknologi, sehingga dapat mengubah cara berpikir, bertindak bahkan mengubah bentuk dan pola hidup manusia yang sama sekali berlainan dengan kehidupan sebelumnya.

Dalam masyarakat seperti itu, peran pendidikan dan guru sangat penting dan strategis, terutama dalam memberikan bimbingan, dorongan, Semangat, fasilitas kepada masyarakat dan peserta didik untuk memperoleh ilmu pengetahuan dan keterampilan menggunakan teknologi. Selain itu, tidak kalah pentingnya adalah peran pendidikan dalam memberikan arahan dan bimbingan agar penguasaan teknologi tidak menjadi bumerang bagi masyarakat, yang disebabkan kurangnya penghayatan terhadap etika.

Pendidikan dan guru dapat menumbuhkan pemahaman etika yang benar, agar kehidupan manusia tidak terancam oleh karena kemajuan teknologi itu sendiri. Manakala pendidikan mengisyaratkan adanya keharusan peserta didik untuk menguasai teknologi, maka tentu tidak kalah pentingnya peran guru itu sendiri untuk lebih dulu menguasai ilmu pengetahuan dan teknologi agar dapat memberikan pengetahuan dan keterampilan teknologi ter-update kepada peserta didiknya.

2. Masyarakat Terbuka

Lahirnya teknologi komunikasi yang demikian maju, membuat dunia menjadi satu seolah tanpa sekat, sehingga komunikasi antar pribadi menjadi makin dekat dan hampir tanpa hambatan, yang pada akhirnya melahirkan masyarakat terbuka. Dalam masyarakat terbuka, antara bangsa satu dengan bangsa lain dapat saling mempengaruhi dalam berbagai hal, termasuk mempengaruhi budaya bangsa lain. Hal itu mengancam kehidupan masyarakat lain oleh karena 
adanya kemungkinan penguasaan atau dominasi oleh mereka yang lebih kuat, yang berprestasi dan yang memiliki modal terhadap masyarakat yang lemah, tidak berdaya dan miskin.

Untuk itu, dalam masyarakat terbuka diperlukan manusia yang mampu mengembangkan kapasitasnya agar menjadi manusia dan bangsa yang kuat, ulet, kreatif, disiplin, dan berprestasi, sehingga tidak menjadi korban dan tertindas oleh zaman yang penuh dengan persaingan. Dalam konteks ini peran pendidikan sangat penting untuk meningkatkan harkat dan martabat suatu masyarakat dan bangsa, agar tidak menjadi bangsa pelayan yang dapat diperintah bangsa lain. Sangat ironis bila bangsa kita yang besar ini tidak mampu bersaing dengan bangsa-bangsa lain, yang hanya mengandalkan kuantitas tanpa kualitas.

3. Masyarakat Madani

Masyarakat madani merupakan wujud dari suatu masyarakat terbuka, di mana setiap individu mempunyai kesempatan yang sama untuk memperoleh ilmu pengetahuan dan keterampilan menggunakan teknologi, berkarya, berprestasi dan memberikan sesuatu sesuai dengan kapasitasnya. Masyarakat madani tumbuh berkembang dalam suatu masyarakat yang saling menghormati, bukan atas dasar asal-usul atau keturunan, tetapi berdasarkan pada kemampuan individual, memiliki toleransi dan tanggungjawab terhadap kehidupan pribadi maupun masyarakatnya, serta menjunjung tinggi rasa kebersamaan untuk mencapai kesejahteraan bersama.

Masyarakat madani tumbuh dan berkembang bukan dengan sendirinya dan bukan tanpa upaya terencana, tetapi masyarakat yang dibangun melalui pendidikan. Kunci terwujudnya masyarakat madani adalah pendidikan, karena melalui pendidikan dapat dibangun sumberdaya yang berkualitas dengan kepribadian yang sesuai dengan budaya serta kesadaran individu hidup berdampingan untuk mencapai tujuan bersama.

\section{Tantangan Guru di Era Global}

Globalisasi telah mengubah cara hidup manusia sebagai individu, sebagai warga masyarakat, dan sebagai warga bangsa. Tidak ada seorang pun yang dapat menghindari arus globalisasi. Setiap individu dihadapkan pada dua pilihan, yakni dia menempatkan 
dirinya dan berperan sebagai pemain dalam arus perubahan globalisasi, atau dia menjadi korban dan terseret derasnya arus globalisasi.

Seiring dengan Karakteristik era global di atas, maka guru juga harus menghadapi tantangan masyarakat global. Di era global, guru sangat dituntut meningkatkan profesionalitasnya sebagai pengajar dan pendidik. Di samping profesionalitas, guru juga harus menghadapi beberapa kata kunci dunia pendidikan yaitu, kompetisi, transparansi, efisiensi, dan kualitas tinggi. Dari segi sosial, masyarakat global akan menjadi sangat peka dan peduli terhadap masalah-masalah demokrasi, hak asasi manusia, dan isu lingkungan hidup.

Menurut Kunandar, ada beberapa tantangan globalisasi yang harus disikapi guru dengan mengedepankan profesionalismenya, yaitu:

1. Perkembangan ilmu pengetahuan dan teknologi yang begitu cepat dan mendasar. Dengan kondisi ini guru harus bisa menyesuaikan diri secara responsif, arif dan bijaksana. Responsif artinya guru harus bisa menguasai dengan baik produk IPTEK, terutama yang berkaitan dengan dunia pendidikan. Tanpa penguasaan IPTEK yang baik, maka guru menjadi tertinggal dan menjadi korban IPTEK serta menjadi guru yang "isoku iki” (aku cuma bisa ini).

2. Krisis moral yang melanda Indonesia. Akibat pengaruh IPTEK dan globalisasi telah terjadi pergeseran nilai-nilai yang ada dalam kehidupan masyarakat. Melalui pendidikan, guru memiliki tantangan tersendiri untuk menanamkan nilai-nilai moral pada generasi muda.

3. Krisis sosial, seperti kriminalitas, kekerasan, pengangguran, dan kemiskinan yang terjadi dalam masyarakat. Akibat perkembangan industri dan kapitalisme, maka muncul masalahmasalah sosial dalam masyarakat. Mereka yang lemah secara pendidikan, akses dan ekonomi akan menjadi korban. Ini merupakan tantangan guru untuk merespons realitas ini melalui dunia pendidikan. Sebab, sekolah merupakan lembaga pendidikan formal yang sudah mendapat kepercayaan dari masyarakat, sehingga harus mampu menghasilkan peserta didik yang siap hidup dalam kondisi dan situasi bagaimanapun. 
4. Krisis identitas sebagai bangsa dan Negara Indonesia. Globalisasi juga telah melunturkan identitas kebangsaan (nasionalisme) generasi muda kita. Untuk itu, guru sebagai penjaga nilai-nilai, termasuk nilai nasionalisme harus mampu memberikan kesadaran kepada generasi muda akan pentingnya jiwa nasionalisme dalam kehidupan berbangsa dan bernegara.

Menanggapi persoalan tersebut, dalam peningkatan kualitas pengajaran, guru harus bisa mengembangkan tiga intelegensi dasar siswa. Yaitu, intelektual, emosional dan moral, tiga unsur itu harus ditanamkan pada diri murid sekuat-kuatnya agar terpatri di dalam dirinya. Hal lain yang harus diperhatikan guru adalah dimensi spiritual siswa.

Intelektual siswa harus luas, agar ia bisa menghadapi era global dan tidak ketinggalan zaman apalagi sampai terbawa arus. Selain itu, dimensi emosional dan spiritual pelajar harus terdidik dengan baik, agar bisa melahirkan perilaku yang baik dan siswa bisa bertahan di antara tarik-ulur pengaruh demoralisasi di era global dengan prinsip spiritualnya.

Di samping itu, untuk mempertahankan profesinya, guru juga harus memiliki kualifikasi pendidikan profesi yang memadai, memiliki kompetensi keilmuan sesuai dengan bidang yang ditekuninya, mampu berkomunikasi baik dengan peserta didiknya, mempunyai jiwa kreatif dan produktif, mempunyai etos kerja dan komitmen tinggi terhadap profesinya. Dengan demikian, tantangan guru di era global tidak akan menggusurnya pada posisi yang tidak baik.

Sebagai seorang profesional, guru seharusnya memiliki kapasitas yang memadai untuk melakukan tugas membimbing, membina, dan mengarahkan peserta didik dalam menumbuhkan Semangat keunggulan, motivasi belajar, dan memiliki kepribadian serta budi pekerti luhur yang sesuai dengan budaya bangsa Indonesia. Guru yang profesional merupakan faktor penentu proses pendidikan yang berkualitas.

Guru dalam era teknologi informasi dan komunikasi sekarang ini bukan hanya sekadar mengajar (transfer of knowledge) melainkan harus menjadi manajer belajar. Hal tersebut mengandung arti, setiap guru diharapkan mampu menciptakan kondisi belajar yang menantang kreativitas dan aktivitas siswa, memotivasi siswa, menggunakan multimedia, multimetode, dan multisumber agar mencapai tujuan pembelajaran yang diharapkan. 
Ada beberapa faktor yang berkaitan dengan beratnya tantangan yang dihadapi oleh profesi keguruan dalam usaha untuk meningkatkan kewibawaannya di mata masyarakat seperti yang dikemukakan oleh Dedi Supriadi sebagai berikut: 1) kekurangjelasan tentang definisi profesi keguruan; 2) desakan kebutuhan masyarakat dan sekolah akan guru berkualitas; 3) sulitnya standar mutu guru dikendalikan dan dijaga; 4) PGRI belum banyak aktif melakukan kegiatan-kegiatan yang secara sistematis dan langsung berkaitan dengan peningkatan profesionalisme guru; 5) perubahan yang terjadi dalam masyarakat melahirkan tuntutan baru terhadap peran (role expectation) yang seharusnya dimainkan oleh guru.

Masyarakat dunia saat ini masuk ke dalam pergaulan era global. Suka atau tidak arus globalisasi adalah arus yang irreversible (tak dapat ditolak). Mengutip Surakhmad, Azyumardi Azra menjelaskan bahwa globalisasi telah menyeret beberapa perubahan (peralihan) paradigma.

Pertama, peralihan dari pendidikan yang mengutamakan nilai kehidupan budaya feodal aristokrasi ke pendidikan yang menggalakkan kehidupan nilai budaya demokrasi. Kedua, peralihan pendidikan yang memihak kepada kepentingan penguasa dan kekuasaan kepada pendidikan yang mengutamakan kepentingan kerakyatan. Ketiga, peralihan pengelolaan pendidikan yang terpusat secara sentralistik kepada pengelolaan pendidikan berbasis kekuatan masyarakat. Keempat, peralihan sikap kependidikan yang mengutamakan keseragaman ke sikap pendidikan yang menghargai keberagaman. Kelima, peralihan pola manajemen pendidikan yang memupuk ketergantungan masyarakat kepada pola manajemen pendidikan yang mengutamakan kemandirian. Keenam, peralihan dari pendidikan yang mengondisi masyarakat takluk kepada gaya pemerintahan penguasa ke pendidikan yang menyadarkan masyarakat tentang pentingnya hukum. Ketujuh, peralihan dari metodologi pendidikan yang mengutamakan pengawetan dan konformisme nilai usang yang disakralkan, kepada metodologi pendidikan yang merintis pengembangan ilmu dan pemanfaatan teknologi. Kedelapan, peralihan dari pandangan kependidikan yang lebih banyak bersifat pelaksanaan kewajiban ke pandangan yang mendidik dan menyadarkan warga Negara mengenai HAM. Kesembilan, peralihan dari orientasi pendidikan yang mengutamakan pelestarian dan keseimbangan dari sudut kepentingan politik ke 
orientasi pendidikan yang mengutamakan perubahan, pertumbuhan dan kemajuan. Kesepuluh, peralihan dari sikap kependidikan yang konformistik, memasung dan punitif, ke sikap pendidikan yang memotivasi, merangsang dan menghargai kreativitas serta inovasi. Kesebelas, peralihan dari pandangan pendidikan yang tertutup ke pandangan pendidikan yang terbuka, fleksibel dan merangsang kerja sama. Kedua belas, peralihan dari program kurikuler yang statis, skolastik, tradisional, ke program kurikuler yang dinamis, riil dan kontekstual.

Kerangka perubahan di atas tentu dengan sendirinya harus membawa perubahan juga pada pola pembelajaran calon-calon guru di perguruan tinggi. Kondisi ini yang menjadi tantangan bagi lembaga pendidikan keguruan, agar dapat menghasilkan lulusan yang tidak hanya sekadar bisa survive, tetapi juga dapat kompetitif menghadapi era global.

\section{E. Tantangan Pengembangan Pendidikan Keguruan di Era Global}

Tantangan globalisasi saat ini makin besar. Persaingan kerja sangat kuat, sehingga lulusan perguruan tinggi yang tidak bermutu tidak akan mendapatkan pekerjaan. Khusus bagi lulusan Fakultas Tarbiyah dan Keguruan serta Fakultas Keguruan dan Ilmu Pendidikan (FKIP), tuntutan banyak yayasan dan sekolah elit terhadap calon guru amat tinggi, seperti guru harus dapat berbahasa Inggris, menguasai informasi, komunikasi dan teknologi (ICT), serta dapat bekerja sama dalam tim. Semua itu jelas menuntut calon guru yang bermutu.

Untuk itu, diperlukan perubahan dalam pendidikan guru, termasuk dalam kurikulumnya. Sayangnya kurikulum yang digunakan khususnya dalam pendidikan Islam kebanyakan belum didasarkan pada asas-asas pembentukan kurikulum yang baik dan bisa menyentuh isu-isu faktual. Kebanyakan kurikulumnya masih kelihatan "usang" dan banyak mengalami problematika Ketika dihadapkan pada kebutuhan globalisasi. Seharusnya kurikulum disesuaikan dengan tuntutan zaman, dan bahan-bahan yang diajarkan tidak hanya tentang model pembelajaran, tetapi juga aplikasi dari banyak penemuan modern.

Selain kurikulum,unsur penting dalam pendidikan guru adalah dosen yang membimbing dan mendampingi para mahasiswa calon guru. Apakah dosennya sudah berkualitas tinggi dan berkompetensi dalam bidangnya? Apakah dosen memberikan 
contoh relasi demokratis dan dialogis dengan mahasiswa selama perjalanan perkuliahan dan dalam banyak kegiatan di Fakultas Tarbiyah dan keguruan atau FKIP? Apakah para mahasiswa Fakultas Tarbiyah dan FKIP sudah dapat merasakan dan mengalami bahwa dosennya memang seorang pendidik yang baik? Semua ini menjadi penting, karena perkuliahan merupakan proses pembelajaran yang panjang dan pada gilirannya nanti membentuk pola pikir dan perilaku mahasiswa calon guru di masa depan.

Dalam kaitan dengan tugas pendidikan, dosen yang bermutu adalah dosen yang melaksanakan tanggung jawab pengajaran, bimbingan, dan latihan keterampilan bagi para mahasiswanya. Sanusi Uwes mengutip Fortunato dan Waddel (1981) merinci tugas pendidikan dan pengajaran menjadi sembilan kegiatan utama, yaitu:

1. Meet all class sections on time

2. Advice and assist students during regularly scheduled office hours

3. Update lecture materials regularly

4. Develop, administer, and score examinations focused on learning experience

5. Provide timely and constructive feedback to student about examinations results

6. Lecture affectively

7. Facilitate class discussions and self-directed learning

8. Cover the course materials as outlined in the syllabus and catalogue

9. Effectively use a variety of media and instructional methods for clarity of presentation and to generate and maintain student interest

Berkaitan dengan tugas pendidikan tersebut dapat dikatakan bahwa penguasaan materi dan keterampilan teknis dalam proses pembelajaran (belajar-mengajar) merupakan dua hal yang mutlak harus dimiliki oleh dosen. Sebab, kedua hal itu memegang peranan kunci untuk meningkatkan kualitas pendidikan di perguruan tinggi.

Secara lebih rinci, guna dapat menciptakan pendidikan guru yang berkualitas, berdasarkan beberapa hasil penelitian DarlingHammond. dan Bransford (Ed.), menyatakan bahwa minimal ada 
tiga elemen penting dalam desain program pendidikan guru yang harus diperbaiki Ketiga elemen tersebut adalah sebagai berikut:

1. Konten pendidikan guru, berkenaan dengan materi yang harus diberikan kepada para mahasiswa, bagaimana cara memberikannya, bagaimana memadukan berbagai materi tersebut sehingga bermakna, termasuk juga bagaimana perluasannya agar mahasiswa memiliki peta kognitif yang akan membantu mereka melihat hubungan antara domain pengetahuan keguruan dengan penggunaannya secara praktis di lapangan untuk mendorong para siswanya belajar.

2. Proses pembelajaran, berkenaan dengan penyusunan kurikulum yang sejalan dengan kesiapan mahasiswa dan mendasar pada materi serta proses pembelajaran praktis yang mampu menimbulkan pemahaman mahasiswa melalui kreativitas aktifnya dalam kelas.

3. Konteks pembelajaran, yang berkenaan dengan penciptaan proses pembelajaran kontekstual guna mengembangkan keahlian praktis mahasiswa. Konteks pembelajaran ini harus diterapkan baik dalam domain-domain materi ajar melalui pembelajaran di komunitas profesional (sekolah).

Terkait dengan pendapat di atas, Lang dan Evans secara lebih gamblang menyatakan bahwa penciptaan program pendidikan bermutu dapat didasarkan atas esensi-esensi program pendidikan guru sebagai berikut:

1. Keberartian teori disertai pengalaman praktisnya.

2. kerjasama antara perguruan tinggi dengan komunitas pendidikan lainnya.

3. Teori dan praktis dalam keterampilan generik dan refleksi serta diskusi tentang efektivitas keterampilan tersebut.

4. Memberikan penekanan proses pada bagaimana caranya mahasiswa belajar untuk meningkatkan kreativitas dan kemampuan berpikir kritis.

5. Kemampuan untuk mengorganisasikan pembelajaran.

6. Penerapan pendekatan konstruktivisme dalam pembelajaran.

7. Penerapan alternatif asesmen dan teori motivasi.

8. Membangun profesionalisme berbasis penelitian.

Mencermati uraian di atas, maka dengan demikian, perlu dilakukan redesain pendidikan keguruan agar dapat menjawab tantangan globalisasi, yaitu:

1. Isi Kurikulum Pendidikan Keguruan 
Kurikulum pada lembaga pendidikan keguruan di era global ini harus lebih dikuatkan "content" keilmuannya. Misalnya, ilmu-ilmu pendidikan, pedagogi, metodologi pendidikan, harus benar-benar dimatangkan. Setelah konten keilmuan kuat secara teori, maka selanjutnya mahasiswa keguruan harus dilatih untuk mempraktekkannya di lapangan. Porsi antara konten keilmuan dengan praktik sebaiknya berkisar $60 \%$ teori, $40 \%$ praktek. Hal ini dilakukan agar program pendidikan guru mampu mendidik calon guru dalam asumsi dasar belajar tentang konsep praktis dalam praktiknya.

Jadi, program pendidikan guru yang berkualitas bukanlah program pendidikan guru yang hanya memberikan pengetahuan berbagai model dan strategi pembelajaran kepada para mahasiswa melainkan yang mampu menerapkan berbagai model dan strategi tersebut kepada mahasiswa, sehingga mahasiswa memperoleh konsep teori dan gambaran aplikasinya sekaligus. Mahasiswa Fakultas Tarbiyah dan Keguruan, misalnya seharusnya melakukan Praktek Pengalaman Lapangan kependidikan (PPLK II) minimal satu semester ( 6 bulan) di sekolah, agar mereka benar-benar dapat mengalami secara nyata pernak-pernik dunia pendidikan yang kompleks. Melalui pengalaman nyata ini, diharapkan keluhan atas ketidaktahuan guru atas berbagai model dan strategi pembelajaran serta ketidakmampuan guru menerapkan berbagai model dan strategi tersebut akan mampu diminimalisasi. Selain itu dengan menerapkan berbagai model dan strategi tersebut langsung kepada para mahasiswa, kreativitas mahasiswa akan meningkat dan para calon guru ini akan memahami benar bahwa menjadi guru pada dasarnya adalah usaha untuk senantiasa menjadi pembelajar yang profesional.

Pertanyaan kedua tentang apa yang dapat dilakukan guru akan mendorong pelaksanaan program pendidikan guru mengarah pada penggalian potensi dan kebutuhan para mahasiswa disesuaikan dengan kondisi nyata kinerja guru di lapangan. Dengan demikian, program pendidikan guru akan senantiasa menitikberatkan pada penciptaan hard skills dan soft skills yang harus dimiliki guru. Hal ini berarti bahwa program pendidikan guru harus mampu memberikan keterampilan profesional kepada para lulusan sekaligus 
menciptakan lulusan yang memiliki kemampuan berpikir tinggi yang akan sangat bermanfaat untuk mengembangkan profesionalisme Ketika mereka sudah menjadi guru kelak. Oleh karenanya, pelaksanaan proses pendidikan pada program pendidikan guru haruslah diarahkan pada upaya mengenalkan dan memainkan mahasiswa sebagai guru selama ia menempuh studinya.

2. Proses Kuliah Berbasis Kontekstual,Konstruktivisme, dan Aktif

Dari segi proses, pembelajaran di lembaga pendidikan keguruan harus menerapkan pendekatan kontekstual, dan konstruktivisme. Hal ini penting, karena pendekatanpendekatan ini akan membentuk Karakter "pembelajar" pada diri mahasiswa calon guru. Sebab, guru di era global bukan hanya mengajar, tetapi juga membentuk Karakter pembelajar pada diri peserta didiknya.

Selain itu, metode-metode pembelajaran aktif juga perlu diterapkan oleh para dosen yang mengajar mahasiswa calon guru. Metode-metode ini dapat merangsang motivasi dan kreativitas mahasiswa, sehingga kelak mereka dapat menjadi guru yang kreatif. Kelengkapan sarana dan prasarana yang sesuai dengan tuntutan globalisasi, pada gilirannya menjadi komponen yang cukup penting untuk diperhatikan dalam lembaga pendidikan keguruan. Guru di era global harus menguasai ICT, sehingga calon-calon guru harus terbiasa dengan proses perkuliahan berbasis ICT.

3. Pendidikan Keguruan Berbasis Penelitian

Pengembangan pendidikan guru yang profesional juga dapat dibentuk melalui peningkatan proses pembelajaran berbasis penelitian. Hal ini berarti bahwa sejak awal para mahasiswa seharusnya sudah diajak untuk melakukan penelitian sederhana pada setiap mata kuliah. Melalui gaya pembelajaran seperti ini, para calon guru diharapkan mampu menemukan esensi guru yang sebenarnya sekaligus membangun kompetensi mereka untuk terampil melaksanakan penelitian Ketika kelak mereka menjadi guru.

Selain itu, pembelajaran berbasis penelitian juga dapat ditafsirkan bahwa proses pembelajaran yang dilakukan di perguruan tinggi senantiasa didasarkan atas hasil-hasil penelitian terkini sejalan dengan scientific vision dan market 
signal sehingga lulusan akan memiliki sejumlah keterampilan yang benar-benar dibutuhkan di lapangan.

4. Pembelajaran berbasis ICT

Kendati bukan segala-galanya, tetapi walau bagaimanapun sarana dan prasarana yang lengkap dan berbasis ICT akan sangat membantu mahasiswa-mahasiswa calon guru untuk belajar lebih baik dan lebih cepat. Era global adalah era yang sangat akrab dengan ICT, sehingga calon-calon guru juga harus dibekali dan dibiasakan dengan proses pembelajaran berbasi ICT, agar tidak menjadi guru yang "isoku iki".

5. Pengelolaan lembaga pendidikan keguruan berbasis mutu

Pada akhirnya, penciptaan program pendidikan yang berkualitas akan sangat bergantung pada kesadaran mutu para pengelolanya. Sehubungan dengan hal ini, para pengelola lembaga pendidikan tinggi keguruan sudah seyogianya menjalankan proses pendidikan berdasarkan penjaminan mutu yang jelas. Dari sisi rekrutmen calon mahasiswa, seharusnya penerimaan mahasiswa Fakultas Tarbiyah dan Keguruan serta FKIP melalui tahap seleksi yang cukup ketat dan kompetitif.

Tes bakat minat, bahkan ukuran fisik yang ideal (baca tinggi badan), sepertinya sudah harus dilakukan mengingat di era global profesi guru akan semakin signifikan perannya. Jangan sampai ada lulusan Fakultas Tarbiyah atau FKIP yang "terpaksa" menjadi guru. Guru adalah profesi mulia yang membutuhkan loyalitas serta totalitas pengabdian, sehingga tidak mungkin dapat dilakukan dengan setengah hati.

Selain itu, para pengelola program pendidikan guru juga diharuskan mampu memberikan pelayanan prima kepada mahasiswa sehingga seluruh program yang dilaksanakannya mampu mengantarkan mahasiswa menjadi SDM yang berkualitas. Dampak peningkatan mutu ini akan bermuara pula pada kepercayaan masyarakat terhadap lembaga pendidikan keguruan tersebut, sehingga keberlangsungan program pendidikan guru tersebut akan terjamin pada masa yang akan datang. 


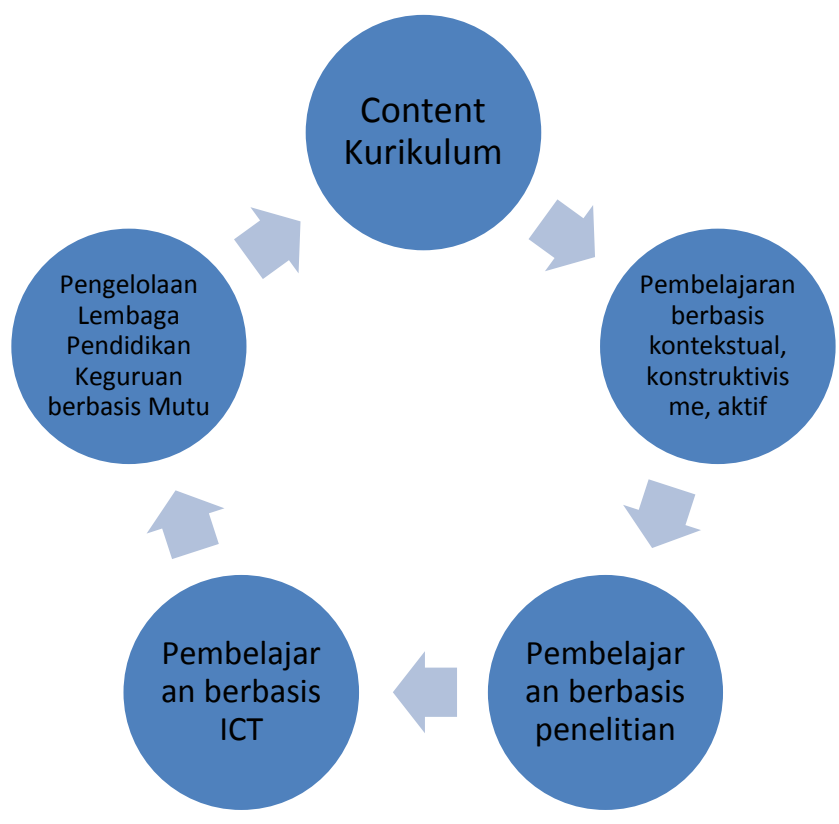

\section{REDESAIN PROGRAM PENDIDIKAN KEGURUAN}

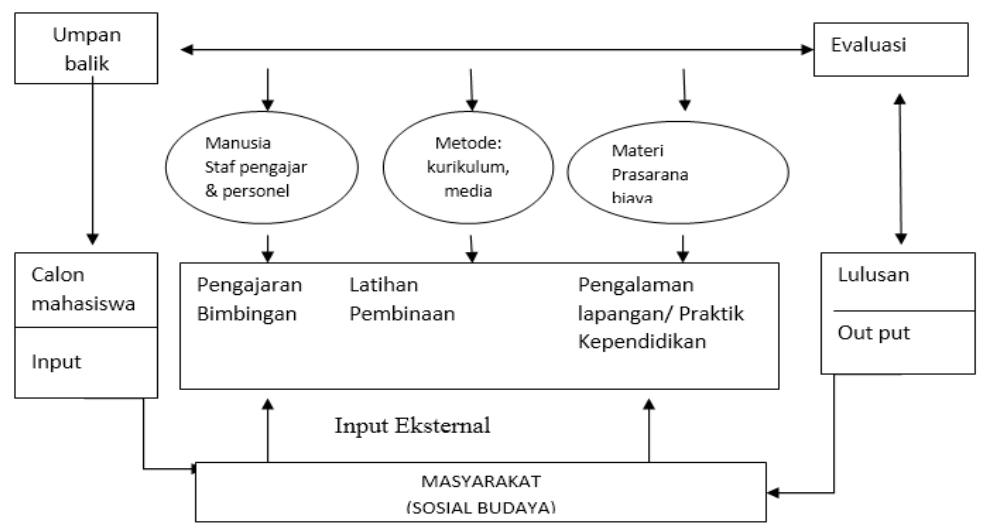

\section{F. Penutup}

Era global memberikan perubahan besar pada tatanan dunia secara menyeluruh dan perubahan itu dihadapi bersama sebagai suatu perubahan yang wajar. Sebab mau tidak mau, siap tidak siap perubahan itu akan terjadi. Era ini ditandai dengan proses kehidupan mendunia, kemajuan ilmu pengetahuan dan teknologi, terutama dalam bidang transformasi dan komunikasi serta 
terjadinya lintas budaya. Era "kesejagadan", begitu istilah Azyumardi Azra untuk merujuk istilah era global.

Perubahan yang dibawa oleh globalisasi ini, mau atau tidak mau juga dialami oleh dunia pendidikan dengan guru sebagai praktisinya. Ada beberapa tantangan yang dihadapi guru di era global dengan harus mengedepankan profesionalismenya, seperti perkembangan ilmu pengetahuan dan teknologi yang begitu cepat dan mendasar; krisis moral yang melanda Indonesia, krisis sosial dan krisis identitas sebagai Bangsa dan Negara Indonesia. Semua itu jelas menuntut calon guru dan pendidik yang bermutu.

\section{Kepustakaan}

Azra, Azyumardi, Pendidikan Islam: Tradisi dan Modernisasi di Tengah Milenium III, Jakarta: Kencana, 2012.

Djamarah, Saiful Bahri, Guru dan Anak Didik dalam Interaksi Edukatif, Jakarta: Rineka Cipta, 2000.

Daradjat, Zakiah, Ilmu Pendidikan Islam, Jakarta: Bumi Aksara, 1991.

Hamalik, Oemar, Pendidikan Guru Berdasarkan Pendekatan Kompetensi, Jakarta: Bumi Aksara, 2009.

Isjoni, Pendidikan sebagai Investasi Masa Depan, Jakarta: Obor, 2006.

Kunandar, Guru Profesional: Implementasi Kurikulum Tingkat Satuan Pendidikan (KTSP) dan Sukses dalam Sertifikasi Guru, Jakarta: Rajawalai Pers, 2007.

Ma'arif, Syamsul, Revitalisasi Pendidikan Islam, Yogyakarta: Graha Ilmu, 2007.

Muhaimin, Pemikiran dan Aktualisasi Pengembangan Pendidikan Islam, Jakarta: Rajawali Pers, 2011.

Rusman, Model-Model Pembelajaran: Mengembangkan Profesionalisme Guru, Jakarta: Rajawali Pers, 2010.

Soetjipto dan Raflis Kosasi, Profesi Keguruan, Jakarta: Rineka Cipta, 2007. 
